Jurnal Matematika UNAND

Vol. VII No. 2 Hal. $33-37$

ISSN : 2303-291X

(C)Jurusan Matematika FMIPA UNAND

\title{
IDEAL PADA RING KOMUTATIF
}

\author{
FEBIE RIANI RAHCMAN, NOVA NOLIZA BAKAR, MONIKA RIANTI HELMI \\ Jurusan Matematika, \\ Fakultas Matematika dan Ilmu Pengetahuan Alam, Universitas Andalas, \\ Kampus Unand Limau Manis, Padang, Indonesia \\ email : feby.riani95@gmail.com
}

\begin{abstract}
Abstrak. Misalkan $R$ adalah ring komutatif dengan unsur satuan dan $I$ adalah ideal pada ring $R$. Dalam tulisan ini dibahas beberapa sifat dari ideal $I$ dengan $I$ adalah ideal prim, radikal dari suatu ideal dan ideal primer. Dibagian akhir tulisan diberikan hubungan antara ideal prim, radikal dari suatu ideal dan ideal primer yaitu jika $I$ adalah ideal primer maka radikal dari $I$ adalah ideal prim.

Kata Kunci: Ring komutatif, ideal, ideal prim, radikal dari suatu ideal, ideal primer
\end{abstract}

\section{Pendahuluan}

Suatu struktur aljabar merupakan suatu sistem yang mengandung dua unsur utama yakni sebuah himpunan dan operasi biner yang didefinisikan di dalamnya. Suatu himpunan yang dilengkapi dengan operasi biner dan memenuhi aksioma tertentu ada yang disebut grup dan ada yang disebut ring. Jika grup merupakan struktur aljabar dengan satu operasi biner, maka ring merupakan struktur aljabar dengan dua operasi biner. Sebuah ring yang operasi perkaliannya bersifat komutatif disebut ring komutatif.

Ideal adalah bagian dari suatu ring dengan struktur yang istimewa. Suatu ideal yang memenuhi beberapa sifat tertentu ada yang disebut ideal prim, radikal dari suatu ideal dan ideal primer.

Pada paper ini akan dibahas bagaimana sifat-sifat dari ideal prim, radikal dari suatu ideal dan ideal primer pada ring komutatif.

\section{Landasan Teori}

\subsection{Grup}

Definisi 2.1. [4] Misalkan G suatu himpunan tak kosong dengan operasi *. Himpunan $G$ disebut grup terhadap operasi *, yang dinotasikan dengan $(G, *)$, jika memenuhi keempat aksioma berikut ini.

(1) Untuk setiap $a, b \in G$ berlaku $a * b \in G$ ( $G$ bersifat tertutup terhadap operasi *).

(2) Untuk setiap $a, b, c \in G$ berlaku $a *(b * c)=(a * b) * c(G$ bersifat asosiatif terhadap operasi $*$ ). 
34 Febie Riani Rahcman dkk

(3) Terdapat suatu unsur di $G$ yang ditulis sebagai e, sehingga $a * e=e * a=a$, untuk setiap $a \in G$ (adanya unsur identitas terhadap operasi $*$ di $G$ ).

(4) Untuk setiap $a \in G$, terdapat $a^{-1} \in G$ sehingga $a * a^{-1}=a^{-1} * a=e$ (Setiap unsur di $G$ mempunyai invers).

Definisi 2.2. [4] Misalkan $(G, *)$ suatu grup. G disebut grup komutatif (abelian) jika setiap $a, b \in G$ berlaku $a * b=b * a$.

\subsection{Ring}

Definisi 2.3. [4] Misalkan $R$ suatu himpunan yang tak kosong. Himpunan $R$ disebut ring jika di $R$ dapat didefinisikan dua operasi biner yang dilambangkan dengan + dan - yang memenuhi aksioma berikut:

(1) $(R,+)$ merupakan grup komutatif.

(2) Untuk setiap $a, b \in R$ berlaku $a \cdot b \in R$ ( $R$ bersifat tertutup terhadap operasi $\cdot)$.

(3) Untuk setiap a,b,c $\in R$ berlaku $a \cdot(b \cdot c)=(a \cdot b) \cdot c(R$ bersifat asosiatif terhadap operasi.).

(4) Untuk setiap $a, b, c \in R$ berlaku:

(i) $a \cdot(b+c)=(a \cdot b)+(a \cdot c)$, (Sifat distributif kiri).

(ii) $(a+b) \cdot c=(a \cdot c)+(b \cdot c)$, (Sifat distributif kanan).

\subsection{Ideal}

Definisi 2.4. [4] Misalkan $(R,+, \cdot)$ suatu ring dan $U \subseteq R$ dengan $U \neq \oslash$. $U$ dikatakan ideal kanan dan ideal kiri dari $R$ jika

(i) $U$ subgrup dari $R$ terhadap + ,

(ii) Untuk setiap $a \in U$ dan $r \in R$ berlaku ar $\in U$ dan $r a \in U$.

Definisi 2.5. [5] Misalkan $R$ suatu ring komutatif dengan unsur satuan 1 dan misalkan $I \neq R$ adalah suatu ideal di $R$, ideal $I$ disebut ideal prim jika ab $\in I$ maka $a \in I$ atau $b \in I$.

Definisi 2.6. [5] Misalkan $R$ suatu ring komutatif dengan unsur satuan 1 dan $I$ adalah ideal pada $R$, maka $\sqrt{I}$ didefinisikan sebagai,

$$
\left\{x \in R \mid x^{n} \in I \text { untuk suatu } n \in \mathbb{N}\right\}
$$

dan $\sqrt{I}$ dikatakan radikal dari suatu ideal $I$.

Definisi 2.7. [1] Misalkan $R$ suatu ring komutatif dengan unsur satuan 1 dan misalkan $I \neq R$ adalah suatu ideal di $R$, ideal $I$ disebut ideal primer jika ab $\in I$ maka $a \in I$ atau $b^{n} \in I$, untuk suatu $n \in \mathbb{N}$.

\section{Ideal pada Ring Komutatif}

\subsection{Ideal Prim}

Proposisi 1. [5] Misalkan $R$ adalah suatu ring komutatif dengan unsur satuan 1 dan $I \neq R$ adalah suatu ideal di $R$, maka pernyataan berikut adalah ekivalen. 
(1) I adalah suatu ideal prim.

(1) Jika $a_{1}, a_{2}, \cdots, a_{n} \in R$ dengan $a_{1} a_{2} \cdots a_{n} \in I$ maka $a_{k} \in I$ untuk suatu $k=$ $1,2, \cdots, n$.

(2) Jika $I_{1}, I_{2}$ adalah ideal di $R$ dengan $I_{1} I_{2} \subseteq I$ maka $I_{1} \subseteq I$ atau $I_{2} \subseteq I$.

(3) Jika $I_{1}, I_{2}, \cdots, I_{n}$ adalah ideal di $R$ dengan $I_{1} I_{2} \cdots I_{n} \subseteq I$ maka $I_{k} \subseteq I$ untuk suatu $k=1,2, \cdots, n$.

\section{Bukti.}

(1) $(1 \Longleftrightarrow 2) I$ adalah ideal prim jika dan hanya jika $a_{1}, a_{2}, \cdots, a_{n} \in R$ dengan $a_{1} a_{2} \cdots a_{n} \in I$ maka $a_{k} \in I$ untuk suatu $k=1,2, \cdots, n$.

$(\Longleftrightarrow) I$ adalah ideal prim, maka untuk setiap $a, b \in R$ dengan $a b \in I$ berlaku $a \in I$ atau $b \in I$, dengan kata lain untuk setiap $a_{1}, a_{2}, \cdots, a_{n} \in R$ dengan $a_{1} a_{2} \cdots a_{n} \in I$ berlaku $a_{1} \in I$ atau $a_{2} \in I, \cdots$, atau $a_{n} \in I$. Ini berarti berlaku $a_{k} \in I$, untuk suatu $k=1,2, \cdots, n$.

(2) $(3 \Longleftrightarrow 4) I_{1}, I_{2}$ adalah ideal di $R$ dengan $I_{1} I_{2} \subseteq I$ maka $I_{1} \subseteq I$ atau $I_{2} \subseteq I$ jika dan hanya jika $I_{1}, I_{2}, \cdots, I_{n}$ adalah ideal di $R$ dengan $I_{1} I_{2} \cdots I_{n} \subseteq I$ maka $I_{k} \subseteq I$ untuk suatu $k=1,2, \cdots, n$.

$(\Longrightarrow)$ Misalkan $I_{1}, I_{2}$ adalah ideal di $R$ dengan $I_{1} I_{2} \subseteq I$ maka $I_{1} \subseteq I$ atau $I_{2} \subseteq I$. Misalkan $I_{1}, I_{2}, \cdots, I_{n}$ adalah ideal di $R$ dengan $I_{1} I_{2} \cdots I_{n} \subseteq I$, akan ditunjukkan $I_{k} \subseteq I$ untuk suatu $k=1,2, \cdots, n$ dengan induksi matematika.

Misalkan $P(n): I_{1}, I_{2}, \cdots, I_{n}$ adalah ideal di $R$ dengan $I_{1} I_{2} \cdots I_{n} \subseteq I$ maka $I_{k} \subseteq I$ untuk suatu $k=1,2, \cdots, n$.

Akan dibuktikan $P(n)$ benar untuk $n=p$. Misalkan $I_{1}, I_{2}, \cdots, I_{p}$ ideal di $R$ dengan $I_{1} I_{2} \cdots I_{p} \subseteq I$.

Perhatikan bahwa

$$
I_{1} I_{2} \cdots I_{p}=\left(I_{1} I_{2} \cdots I_{p-1}\right) I_{p} \subseteq I,
$$

diperoleh $I_{1} I_{2} \cdots I_{p-1} \subseteq I$ atau $I_{p} \subseteq I$, ini berarti untuk setiap $I_{1}, I_{2}, \cdots, I_{p}$ ideal di $R$ dengan $I_{1} I_{2} \cdots I_{p} \subseteq I$ berlaku $I_{k} \subseteq I$ untuk suatu $k=1,2, \cdots, p$. $(\Longleftarrow)$ Dari $I_{1}, I_{2}$ adalah ideal di $R$ dengan $I_{1} I_{2} \subseteq I$ maka berdasarkan premis diperoleh $I_{1} \subseteq I$ atau $I_{2} \subseteq I$.

(3) $(1 \Longleftrightarrow 3) I$ adalah suatu ideal prim jika dan hanya jika $I_{1}, I_{2}$ adalah ideal di $R$ dengan $I_{1} I_{2} \subseteq I$ maka $I_{1} \subseteq I$ atau $I_{2} \subseteq I$.

$(\Longrightarrow)$ Misalkan $I$ adalah suatu ideal prim dan $I_{1}, I_{2}$ adalah ideal di $R$ dengan $I_{1} I_{2} \subseteq I$, akan ditunjukkan $I_{1} \subseteq I$ atau $I_{2} \subseteq I$.

Andaikan $I_{1} \nsubseteq I$ dan $I_{2} \nsubseteq I$. Ambil $x_{1} \in I_{1} \backslash I$ dan $x_{2} \in I_{2} \backslash I$, karena $x_{1} x_{2} \in I$ dan $I$ adalah ideal prim, maka $x_{1} \in I$ atau $x_{2} \in I$. Hal ini kontradiksi dengan pemilihan $x_{1} x_{2} \notin I$, sehingga haruslah $I_{1} \subseteq I$ atau $I_{2} \subseteq I$.

\subsection{Radikal dari Suatu Ideal}

Teorema 3.1. [5] Misalkan $I$ dan $J$ adalah ideal pada ring komutatif $R$ dengan unsur satuan 1, maka:

(1) $\sqrt{I}$ adalah ideal di $R$ dengan $I \subseteq \sqrt{I} \subseteq R$. 
(2) Jika $I \subseteq J$ maka $\sqrt{I} \subseteq \sqrt{J}$.

(3) $\sqrt{\sqrt{I}}=\sqrt{I}$.

\section{Bukti.}

(3) $\sqrt{\sqrt{I}}=\sqrt{I}$.

(a) Ambil $a \in \sqrt{\sqrt{I}}$, akan ditunjukkan $a \in \sqrt{I}$.

Dari $a \in \sqrt{\sqrt{I}}$, diperoleh $a \in R$ dan $a^{n} \in \sqrt{I}$, untuk suatu $n \in \mathbb{N}$, dengan kata lain $\left(a^{n}\right)^{m} \in I$, untuk suatu $m \in \mathbb{N}$.

(b) Ambil $b \in \sqrt{I}$, akan ditunjukkan $b \in \sqrt{\sqrt{I}}$.

Dari $b \in \sqrt{I}$, diperoleh $b \in R$ dan $b^{n} \in I$ untuk suatu $n \in \mathbb{N}$, karena $b^{n} \in I$ dan $I \subseteq \sqrt{I}$ maka $b^{n} \in \sqrt{I}$ untuk suatu $n \in \mathbb{N}$, dengan kata lain $b \in \sqrt{\sqrt{I}}$.

\subsection{Ideal Primer}

Proposisi 2. [5] Misalkan $R$ adalah suatu ring komutatif dengan unsur satuan 1 dan $I \neq R$ adalah suatu ideal di $R$, maka pernyataan berikut adalah ekivalen.

(1) I adalah suatu ideal primer.

(2) Jika $a_{1}, a_{2}, \cdots, a_{n} \in R$ dengan $a_{1} a_{2} \cdots a_{n} \in I$ maka $a_{k} \in \sqrt{I}$ untuk suatu $k=1,2, \cdots, n$.

(3) Jika $I_{1}, I_{2}$ adalah ideal di $R$ dengan $I_{1} I_{2} \subseteq I$ maka $I_{1} \subseteq \sqrt{I}$ atau $I_{2} \subseteq \sqrt{I}$.

(4) Jika $I_{1}, I_{2}, \cdots, I_{n}$ adalah ideal di $R$ dengan $I_{1} I_{2} \cdots I_{n} \subseteq I$ maka $I_{k} \subseteq \sqrt{I}$ untuk suatu $k=1,2, \cdots, n$.

Pembuktian untuk proposisi ideal primer ini analog dengan pembuktian proposisi pada ideal prim.

Proposisi 3. [5] Misalkan $R$ adalah suatu ring komutatif, jika $I$ adalah ideal primer, maka $\sqrt{I}$ adalah ideal prim.

Bukti. Misalkan $R$ adalah suatu ring komutatif dan $I$ adalah ideal primer, akan ditunjukkan $\sqrt{I}$ adalah ideal prim, yaitu dengan menunjukkan untuk setiap $a b \in$ $\sqrt{I}$, maka $a \in \sqrt{I}$ atau $b \in \sqrt{I}$.

Ambil $a b \in \sqrt{I}$, diperoleh $a b \in R$ dan $(a b)^{n} \in I$, untuk suatu $n \in \mathbb{N}$.

Perhatikan bahwa:

$$
(a b)^{n}=a^{n} b^{n} \in I
$$

$I$ adalah ideal primer, mengakibatkan $a^{n} \in I$ atau $\left(b^{n}\right)^{m} \in I$, untuk suatu $m \in \mathbb{N}$, sehingga berdasarkan Definisi radikal dari suatu ideal diperoleh $a \in \sqrt{I}$ atau $b \in \sqrt{I}$. Berdasarkan pembuktian di atas terbukti bahwa $\sqrt{I}$ adalah suatu ideal prim.

\section{Kesimpulan}

Pada paper ini telah dibahas sifat-sifat dari ideal prim, radikal dari suatu ideal dan ideal primer pada ring komutatif. Misalkan $R$ adalah suatu ring komutatif dengan unsur satuan 1 dan $I \neq R$ adalah suatu ideal di $R$, maka pernyataan berikut adalah ekivalen. 
(1) I adalah suatu ideal prim.

(2) Jika $a_{1}, a_{2}, \cdots, a_{n} \in R$ dengan $a_{1} a_{2} \cdots a_{n} \in I$ maka $a_{k} \in I$ untuk suatu $k=$ $1,2, \cdots, n$.

(3) Jika $I_{1}, I_{2}$ adalah ideal di $R$ dengan $I_{1} I_{2} \subseteq I$ maka $I_{1} \subseteq I$ atau $I_{2} \subseteq I$.

(4) Jika $I_{1}, I_{2}, \cdots, I_{n}$ adalah ideal di $R$ dengan $I_{1} I_{2} \cdots I_{n} \subseteq I$ maka $I_{k} \subseteq I$ untuk suatu $k=1,2, \cdots, n$.

Misalkan $I$ dan $J$ adalah ideal pada ring komutatif $R$ dengan unsur satuan 1, maka

(1) $\sqrt{I}$ adalah ideal di $R$ dengan $I \subseteq \sqrt{I} \subseteq R$.

(2) Jika $I \subseteq J$ maka $\sqrt{I} \subseteq \sqrt{J}$.

(3) $\sqrt{\sqrt{I}}=\sqrt{I}$.

Misalkan $R$ adalah suatu ring komutatif dengan unsur satuan 1 dan $I \neq R$ adalah suatu ideal di $R$, maka pernyataan berikut adalah ekivalen.

(1) I adalah suatu ideal primer.

(2) Jika $a_{1}, a_{2}, \cdots, a_{n} \in R$ dengan $a_{1} a_{2} \cdots a_{n} \in I$ maka $a_{k} \in \sqrt{I}$ untuk suatu $k=1,2, \cdots, n$.

(3) Jika $I_{1}, I_{2}$ adalah ideal di $R$ dengan $I_{1} I_{2} \subseteq I$ maka $I_{1} \subseteq \sqrt{I}$ atau $I_{2} \subseteq \sqrt{I}$.

(4) Jika $I_{1}, I_{2}, \cdots, I_{n}$ adalah ideal di $R$ dengan $I_{1} I_{2} \cdots I_{n} \subseteq I$ maka $I_{k} \subseteq \sqrt{I}$ untuk suatu $k=1,2, \cdots, n$.

Selanjutnya diperoleh hubungan antara ideal prim, radikal dari suatu ideal dan ideal primer yaitu misalkan $R$ adalah suatu ring komutatif, jika $I$ adalah ideal primer, maka $\sqrt{I}$ adalah ideal prim.

\section{Ucapan Terima kasih}

Penulis mengucapkan terima kasih kepada Bapak Narwen M.Si, Bapak Dr. Jenizon, dan Ibu Dr. Yanita yang telah memberikan masukan dan saran sehingga paper ini dapat diselesaikan dengan baik.

\section{Daftar Pustaka}

[1] Atiyah, Michael Francis, MacDonald, I.G. 1969. Introduction to Commutative Algebra, Westview Press.

[2] Burton, David M. 2007. Elementary Number Theory, Sixth Edition. McGrawHill Companies, New York.

[3] Dave, W.M. and Joy Morris. 2009. Proofs and Concepts the Fundamental of Abstract Mathematics. State University of Newyork, Newyork.

[4] Herstein, I.N. 1975. Topics in Algebra. Edisi ke-2. John Wiley and Sons, New York.

[5] Spindler Karlheins. 1994. Abstract Algebra with Applications. Volume II. Rings and Fields. Library of Congress Cataloging in Publication Data, Berlin. 